\title{
Influence of a Combination of Agricultural Chemicals on Embryos of the Endangered Gold-Striped Salamander (Chioglossa lusitanica)
}

\author{
M. E. Ortiz-Santaliestra • M. J. Ferná ndez-Benéitez • \\ M. Lizana • A. Marco
}

\begin{abstract}
Pollution from agrochemicals may be contributing to the global decline of amphibian populations. Environmentally relevant concentrations of a fertiliser, ammonium nitrate, and a commercial formulation of the herbicide glyphosate Roundup Plus were tested on the embryonic development of Chioglossa lusitanica. This study introduces new data at three different levels. First, we provide previously unknown information about hatchling traits of C. lusitanica. Second, we present the first ecotoxicological study of this endangered species, to which environmental pollution is considered a major threat. Third, we conduct the first experiment with an amphibian species exposed to a mixture of a glyphosate-based herbicide and a nitrogenous fertiliser. Control individuals hatched with an average $( \pm \mathrm{SD})$ total length of $18.77( \pm 2.02)$ $\mathrm{mm}$ and at an average Harrison's developmental stage of $44.58( \pm 1.24)$. Mean hatching time among controls was $11.52( \pm 1.29)$ weeks. None of the chemicals or their interaction produced lethal effects; however, a significant interaction was found when analysing total length at hatching. Individuals exposed to the herbicide hatched at a larger size than controls, and this effect was especially clear when the fertiliser was added to the water. The
\end{abstract}

M. E. Ortiz-Santaliestra . M. J. Fernández-Benéitez . M. Lizana Departamento de Biología Animal, Universidad de Salamanaca, Campus Miguel de Unamuno, 37007 Salamanca, Spain

\section{A. Marco}

Estación Biológica de Doñana CSIC, C/ Américo Vespucio s/n, 41092 Sevilla, Spain

M. E. Ortiz-Santaliestra (\&)

Instituto de Investigación en Recursos Cinegéticos, UCLMCSIC-JCCM, Ronda de Toledo s/n, 13071 Ciudad Real, Spain e-mail: manuele.ortiz@uclm.es absence of pollutant-related mortality or severe sublethal effects is in agreement with most studies indicating a high tolerance of amphibian embryos to agrochemicals. However, further research considering other life stages and additional natural factors (i.e., predators, food availability) is needed to estimate the ecological impact of chemical mixtures on C. lusitanica.

Agricultural chemicals, acting singly or in combination with other stressors, are receiving increasing attention as a potential cause of amphibian declines (Mann et al. 2009). Many studies support the idea that mixtures of chemical substances originating from agricultural activities may negatively affect amphibian populations, with combinations of factors often having interactive effects not predicted from single-factor studies (e.g., Relyea and Mills 2001; Blaustein et al. 2003; Boone and James 2003; Boone et al. 2005, 2007; Johnson et al. 2006). For instance, Relyea (2009) analysed the effects of 5 herbicides and 5 pesticides, either alone or in combination, on Rana pipiens and Hyla versicolor tadpoles. He found that the toxicity associated with the insecticides was greater than that associated with the herbicides. Only two compounds, both insecticides, decreased R. pipiens larval survival when applied alone: endosulfan (16\% of survival) and diazinon (76\%). However, a mixture of all 5 insecticides and a mixture of all 10 pesticides eliminated almost $100 \%$ of tadpoles. Interestingly, no effects on $\mathrm{H}$. versicolor were detected and, as a result, tadpoles of this species grew nearly twice as large due to decreased competition with R. pipiens.

Likewise, deleterious consequences of nitrogenous fertilizers have been noted in response to their combination with other environmental factors, such as pesticides (Boone et al. 2005), UV-B radiation (Hatch and Blaustein 2000, 
2003; Macías et al. 2007), or low pH (Hatch and Blaustein 2000). In addition, Egea-Serrano et al. (2009) demonstrated that the exposure of amphibian larvae to combinations of different nitrogenous compounds affected larval survival and food consumption more severely than did exposure to single compounds.

Analysis of the sensitivity of amphibians to cocktails of agricultural chemicals, such as pesticides, herbicides, or synthetic fertilisers, is relevant from an ecologic perspective. Agricultural runoff may simultaneously transport different substances from crop fields to adjacent ponds where many amphibian species breed and develop. For example, the common herbicide atrazine is generally applied to crop fields at the same time as nitrogen-based fertilisers (Eisler 1989). Therefore, both kinds of pollutants may appear in the field at the same time and affect amphibian aquatic stages to a greater degree than when occurring alone (Sullivan and Spence 2003; Orton et al. 2006).

Another widely used herbicide is glyphosate, which is used to control and remove weeds from all kind of crops (Giesy et al. 2000). This compound is applied in many different forms, corresponding to its diverse commercial formulations. The most used glyphosate formulation is Roundup (Monsanto, Saint Louis, MO), which is presented as an aqueous solution of glyphosate isopropylamine salt with the surfactant polyoxyethylene tallowamine (POEA). POEA is added to the formulation to facilitate penetration through the plant cuticle. Although glyphosate is presented as a benign herbicide because it targets vegetal tissues, the toxicity of POEA on aquatic fauna challenges this reputation for most glyphosate formulations to which POEA is added (Giesy et al. 2000). In fact, several studies conducted to assess the effects of Roundup on amphibians have demonstrated that the toxicity of the formulation comes mainly from POEA (Mann and Bidwell 1999), and that other glyphosate formulations that do not include POEA as a surfactant are less toxic to these animals (Howe et al. 2004).

Because Roundup is primarily registered for terrestrial application (e.g., in countries such as Spain, where aquatic use is approved, it is restricted to irrigation ditches), the assessment of its real impact on aquatic environments has generated some controversy. Thompson et al. (2006) questioned the environmental relevance of the experiment conducted by Relyea (2005a) to analyze the effects of Roundup on aquatic communities. They argued that the kind of application of Roundup used in that experiment, i.e., applied directly and uniformly to water surfaces, represented an illegal or unlikely scenario. Thompson et al. (2006) suggested that given that Roundup is not intended for direct application to surface waters, the concentration of glyphosate reported by Relyea (2005a) as lethal to amphibians (i.e., $3.1 \mathrm{mg} / \mathrm{L}$ glyphosate acid equivalents [a.e.]) would not be consistent with what these animals are exposed to in an ecologically realistic scenario. In his reply to Thompson et al. (2006), Relyea (2006) made some arguments for examining Roundup's effects in aquatic systems after direct application of the herbicide to surface waters; for example, he used the own words of Thompson et al. (2004) who had pointed out that small wetlands where many amphibians breed are difficult to avoid during aerial application of herbicides as well as the fact that there are no requirements to protect those small wetlands with no-spray buffer zones. Giesy et al. (2000) reported glyphosate concentrations in surface waters B $1.7 \mathrm{mg}$ a.e./L, and Relyea (2006) also reviewed a number of studies that estimated worst-case scenario concentrations in aquatic environments of $7.6 \mathrm{mg}$ a.e./L (e.g., Mann and Bidwell 1999).

Ammonium nitrate is another widely used agricultural chemical, and its application on crop fields has increased in parallel with the use of inorganic nitrogenous fertilisers (Vitousek et al. 1997). Ammonium nitrate is known to have a wide variety of negative effects on amphibians, from lethal effects on embryos, larvae, and terrestrial stages, to decreased growth, delayed development, abnormalities, and behavioural alterations (e.g., Watt and Oldham 1995; Oldham et al. 1997; Schuytema and Nebeker 1999; Ortiz et al. 2004).

The aim of this study was to analyse the combined effects of ammonium nitrate and the glyphosate formulation Roundup Plus (36\% glyphosate and 8.5\% POEA; Monsanto Europe, Antwerp, Belgium) on gold-striped salamander (Chioglossa lusitanica) embryos. C. lusitanica is an endemic salamander from the Northwestern Iberian Peninsula (Vences 2009). Because of the scarcity of known breeding locations, little is known about this species' reproductive biology. In particular, to date, nothing is known about certain life history traits, such as size or stage at hatching. Therefore, the experimental incubation of nonexposed embryos used as controls will provide new data on the reproductive biology of the species. The species is characterised as "vulnerable" in the IUCN red list of threatened species (Arntzen et al. 2009) and, although agrochemical pollution of the streams where it lives is one of its major threats (Arntzen et al. 2009), we are unaware of the existence of information regarding the species' sensitivity to any specific contaminant. Glyphosate has been used for the removal of invasive plants from the PenedaGêres National Park (Northern Portugal) (Fontes 2008), where some of the populations in better status of conservation are found. In addition, the area is covered by eucalyptus (Eucalyptus globulus) crops, which are usually fertilised with diverse forms of inorganic nitrogen (e.g., Carneiro et al. 2008). 

Materials and Methods

All of the animals used in the present study were cared for in accordance with the European Council Directive 86/609/ EEC of November 24, 1986, on the approximation of laws, regulations, and administrative provisions of the European Union Member States regarding the protection of animals used for experimental and other scientific purposes. The Instituto da Conservação da Natureza of Portugal provided the permission to collect the animals.

In October 2004, we collected 200 C. lusitanica eggs from an abandoned mine in Valongo (northwest Portugal) $\left(41^{\circ} 10^{\circ} \mathrm{N}, 8^{\circ} 29^{\circ} \mathrm{W}\right)$. The conditions inside the mine are total darkness, humidity [90\%, and a constant temperature of $14^{\circ} \mathrm{C}$ throughout the year (see Sequeira et al. 2003 for details). At the time of collection, the eggs were attached to the walls, between 5 and $20 \mathrm{~cm}$ above the water surface, and their developmental stages were Harrison's 8 to 10 (Harrison 1969). To collect eggs from different female animals, eggs were collected from five different points along the mine. We did not take water samples for chemical analyses but, according to the developmental stage of the embryos, we estimated that they had been laid within the last 72 hours, and thereby no potential selection of tolerant individuals could be expected. The eggs were transported to the laboratory, where the experimental incubation began 24 hours after collection.

On arrival at the laboratory, we randomly selected 180 eggs, which were submerged in 36 containers (5 eggs/ container) with $50 \mathrm{~mL}$ water filtered with active carbon. Experimental conditions were set up to simulate the interior of the mines where eggs came from, namely, a constant water temperature of $14^{\circ} \mathrm{C}$ and permanent darkness. With this purpose, the containers were introduced, but not submerged, into a bath of $15 \mathrm{~L}$ water maintained at $14^{\circ} \mathrm{C}$ with a Selecta $285 \mathrm{~W}$ refrigerator (J. P. Selecta SA, Abrera, Spain). The water temperature of the containers was checked periodically and did not vary more than $0.5^{\circ} \mathrm{C}$ from the temperature in the bath. To provide darkness, the entire experimental installation was maintained in a totally dark enclosure, which was only opened to check the animals and change the water in the containers.

Each container was randomly assigned to an initial concentration of ammonium nitrate $(0,22.6$, and $90.3 \mathrm{mg}$ $\left.\mathrm{N}-\mathrm{NO}_{3} \mathrm{NH}_{4} / \mathrm{L}\right)$ and of Roundup Plus (0, 2.8, and $5.6 \mathrm{mg} / \mathrm{L}$ [corresponding to 0,1 , and $2 \mathrm{mg}$ glyphosate/L and $0,0.24$, and $0.47 \mathrm{mg}$ POEA/L]). Ammonium nitrate experimental concentrations were consistent with those measured in wetlands where amphibians breed (e.g., Egea-Serrano et al. 2009). Likewise, as discussed previously, glyphosate experimental concentrations would be within the expected range in aquatic environments (Giesy et al. 2000). We chose those concentrations because they represented, for both chemicals and according to previous studies, a lethal and a sublethal level for amphibian aquatic stages (e.g., Mann and Bidwell 1999; Ortiz et al. 2004; Relyea 2005a, b; OrtizSantaliestra et al. 2006). Initial concentrations of ammonium nitrate were obtained after pipetting the corresponding volume of a stock solution prepared with $99 \%$ pure ammonium nitrate salt (Merck, Darmstaad, Germany). The initial concentrations of Roundup Plus were obtained by pipetting directly from the commercial product. Each combination of treatments (ammonium nitrate 9 Roundup Plus) was replicated four times. The water of every container was changed and the initial levels of both substances were reset weekly.

The experiment began when eggs were at Harrison stage 12 and finished after 15 weeks, when all the individuals had either hatched or died. Mortality rates were calculated weekly, and individuals were staged according to the system detailed in Table 1. We checked the experiment weekly to avoid excessive exposure of embryos to the light because they are accustomed to developing in conditions of total darkness. The reason why we decreased the number of developmental stages from the 46 considered by Harrison (1969) to the 11 considered for the present study was to adapt the staging system to the low checking frequency. As explained later in the text, the average duration of each developmental stage was approximately 1 week, which made our staging system suitable for this low staging frequency. At hatching, individuals were measured (total length snout to tail tip) with a digital calliper to the nearest $0.01 \mathrm{~mm}$. In addition, we recorded hatching time and Harrison developmental stage at hatching.

To analyse the effects of ammonium nitrate and Roundup Plus on embryonic survival, we conducted a twoway repeated measures analysis of variance (RM ANOVA) with the increase in mortality rate (arcsin of square root transformed) over time as the dependent variable. To analyse the effects of the pollutants on embryonic development, we used another RM ANOVA with the sequence of mean times (log transformed) necessary to reach each developmental stage as the dependent variable. The influence of both chemicals on hatching time was tested with a two-way ANOVA using the mean hatching time (log transformed) as the dependent variable. Finally, the length and developmental stage of the hatchlings were log transformed and analysed using two-way analysis of covariance (ANCOVA) with transformed hatching time as covariate. Mean values per container were considered for dependent variables in all statistical analyses. SPSS 17.0 for Windows (SPSS, Chicago, IL) was used for statistical analyses. Posthoc statistical power was calculated for each test using the application GPower 3.1 (Franz Faul, Universität Kiel, Germany) (Faul et al. 2009). 
Table 1 Relation between developmental stages used in the present study and those of Harrison (1969)

\begin{tabular}{lll}
\hline This study & Harrison (1969) & Description \\
\hline 1 & $13-15$ & Neural crest formation \\
2 & $16-19$ & Development of neural folds \\
3 & $20-21$ & Neural tube formation \\
4 & $22-25$ & Head differentiation \\
5 & $26-28$ & Elongation of the body, tail bud present \\
6 & $29-31$ & Tail bud differentiated, nasal orifices opened \\
7 & $32-34$ & Heart development \\
8 & $35-36$ & Development of branchial nodes \\
9 & $37-40$ & Fore limbs present \\
10 & $41-43$ & Hind limbs present \\
11 & $44-46$ & Finger differentiation \\
\hline
\end{tabular}

Results

Statistical power was $[0.8$ for all tests. At the end of the experiment, the mortality rate of controls was $11.3 \%$, whereas embryos exposed to the highest concentrations of ammonium nitrate and Roundup Plus showed mortality rates of $62.5 \%$ and $31.3 \%$, respectively (Fig. 1). However, as showed by the RM ANOVA, neither this pollutantrelated decrease in survival, nor the interaction between chemicals, was statistically significant (Table 2).

Embryonic developmental rate was similar across treatments (Fig. 2) and was not significantly affected by ammonium nitrate, Roundup Plus, or their combined action (Table 2). The weekly developmental rate (mean number of stages of development advanced/week) per treatment varied from 0.91 to 1.02 and also was not influenced by the chemical treatments ( $\mathrm{p}$ - 0.05). These values, indicating that embryos developed at an approximate rate of one stage per week, suggest a low risk of artificially increasing or decreasing differences among treatments in developmental

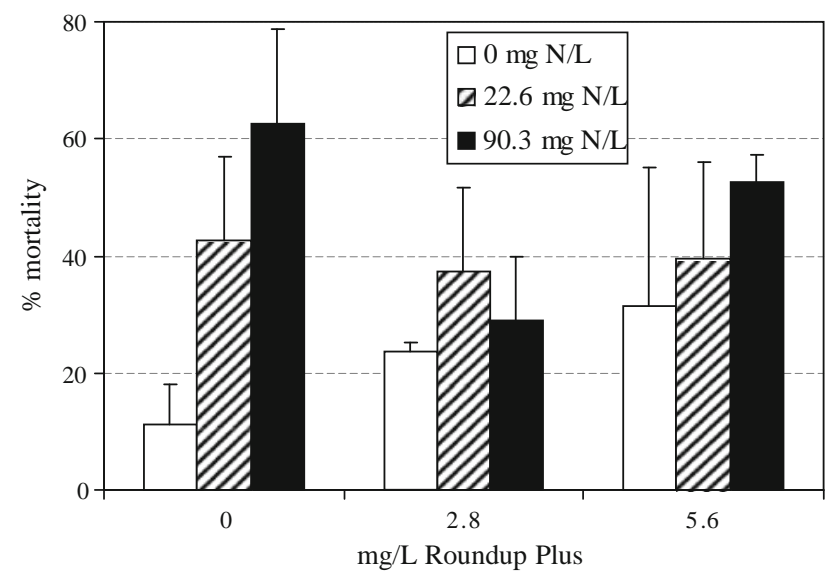

Fig. 1 Mortality rates (?SE) of C. lusitanica embryos exposed to different concentrations of ammonium nitrate (mg N/L) and Roundup Plus rates. If the variability of developmental stages per week had been too high, checking containers once per week would have been insufficient to accurately estimate developmental rates.

Control individuals hatched with an average $( \pm S D)$ total length of 18.77 ( \pm 2.02$) \mathrm{mm}$ (range 13.15 to 20.40) and at an average developmental stage of $44.58( \pm 1.24)$ (range 42 to 46; Harrison [1969]). Mean hatching time among controls was $11.52( \pm 1.29)$ weeks (range 9 to 13$)$. These data were calculated from a sample of 17 individuals and constitute, to the best of our knowledge, the first published information on the hatching traits of C. lusitanica.

Exposure to ammonium nitrate did not affect the hatching time, length, or stage (Table 3). Roundup Plus, however, produced a positive effect on total length at hatching that was also influenced by the interaction between the herbicide and the fertiliser (Table 3). The animals exposed to Roundup Plus were larger than controls at hatching, and this difference was especially clear in those exposed to the ammonium nitrate treatments (Fig. 3). Roundup Plus, or its interaction with ammonium nitrate, did not have any effect on hatching time or developmental stage (Fig. 3).

\section{Discussion}

The results of the present ecotoxicologic study provide novel information on the biology of C. lusitanica, an endangered species (Arntzen et al. 2009), by reporting previously unknown data on its hatching traits (length, time, and developmental stage). Only a summarised description of larval morphology at hatching has been provided by Vences (2009). According to the few field studies on the species' breeding phenology in Northern Portugal, earlier clutches have been found in August, with hatched larvae in October, although later clutches have been found in December, with hatched larvae in January (Arntzen 1981; 
Table 2 Results of RM ANOVA of the effects of $\mathrm{NO}_{3} \mathrm{NH}_{4}$ and Roundup on mortality and development rates of C. lusitanica embryos

\begin{tabular}{|c|c|c|c|c|c|}
\hline Variable & Source of variation & Sum of squares & df & $\mathrm{F}$ & $\mathrm{p}$ \\
\hline \multirow[t]{5}{*}{ Mortality (within subjects) } & Time & 4.9368 & 1 & 45.579 & 6.001 \\
\hline & Time $9 \mathrm{NO}_{3} \mathrm{NH}_{4}$ & 0.0420 & 2 & 0.194 & 0.825 \\
\hline & Time 9 Roundup & 0.0500 & 2 & 0.231 & 0.796 \\
\hline & Time $9 \mathrm{NO}_{3} \mathrm{NH}_{4} 9$ Roundup & 0.1721 & 4 & 0.397 & 0.809 \\
\hline & Error & 2.9244 & 27 & & \\
\hline \multirow[t]{4}{*}{ Mortality (between subjects) } & $\mathrm{NO}_{3} \mathrm{NH}_{4}$ & 9.2594 & 2 & 2.280 & 0.122 \\
\hline & Roundup & 1.2933 & 2 & 0.318 & 0.730 \\
\hline & $\mathrm{NO}_{3} \mathrm{NH}_{4} 9$ Roundup & 8.2788 & 4 & 1.109 & 0.415 \\
\hline & Error & 54.8184 & 27 & & \\
\hline \multirow[t]{5}{*}{ Development (within subjects) } & Time & 46.5801 & 1 & 9447.323 & $\checkmark .001$ \\
\hline & Time $9 \mathrm{NO}_{3} \mathrm{NH}_{4}$ & 0.0036 & 2 & 0.364 & 0.698 \\
\hline & Time 9 Roundup & 0.0003 & 2 & 0.029 & 0.971 \\
\hline & Time $9 \mathrm{NO}_{3} \mathrm{NH}_{4} 9$ Roundup & 0.0210 & 4 & 1.065 & 0.395 \\
\hline & Error & 0.1233 & 25 & & \\
\hline \multirow[t]{4}{*}{ Development (between subjects) } & $\mathrm{NO}_{3} \mathrm{NH}_{4}$ & 0.0094 & 2 & 0.679 & 0.516 \\
\hline & Roundup & 0.0193 & 2 & 1.395 & 0.267 \\
\hline & $\mathrm{NO}_{3} \mathrm{NH}_{4} 9$ Roundup & 0.0381 & 4 & 1.375 & 0.271 \\
\hline & Error & 0.1731 & 25 & & \\
\hline
\end{tabular}

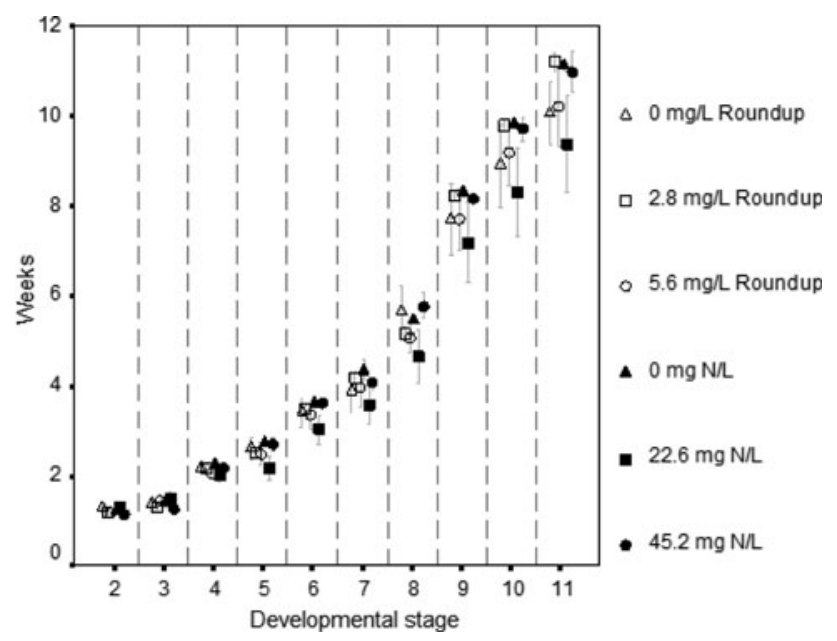

Fig. 2 Mean time (?SE) spent by C. lusitanica embryos exposed to different concentrations of ammonium nitrate (mg N/L) or Roundup Plus to reach every developmental stage as defined in Table 1 . To simplify, only data from controls and single-chemical exposures are shown

Vences 1990; Sequeira et al. 2003). The mean hatching time reported in the present study (11.52 weeks) would be in agreement with the estimations corresponding to late summer/early autumn clutches, as might be expected from the fact that we collected the eggs in October.

Neither ammonium nitrate nor Roundup Plus showed significant lethal effects on C. lusitanica embryos, although exposure to the fertiliser decreased survival in a rather indicative manner. The absence of significant lethal effects of inorganic nitrogenous compounds on urodele embryos is a common finding in the few studies dealing with this question. Laposata and Dunson (1998) observed no significant variation in the hatching success of Ambystoma maculatum and A. jeffersonianum among different nitrate concentrations ranging from 0 to $9.03 \mathrm{mg} \mathrm{N}-\mathrm{NO}_{3}{ }^{-} / \mathrm{L}$, and Meredith and Whiteman (2008) did not find significant mortality at $500 \mathrm{mg} \mathrm{N}-\mathrm{NO}_{3}{ }^{-} / \mathrm{L}$ for A. mexicanum. GriffisKyle (2007) reported that the proportion of A. tigrinum eggs that hatched after being exposed to nitrite concentrations between 0 and $6.1 \mathrm{mg} \mathrm{N}-\mathrm{NO}_{2}^{-} / \mathrm{L}$ was always [86\%. Finally, ammonium nitrate at the same concentrations as used in the present study did not cause significant mortality in Triturus pygmaeus (Ortiz-Santaliestra et al. 2007) or Lissotriton boscai embryos (Ortiz-Santaliestra, 2010, unpublished data).

Our results regarding the absence of lethal effects of Roundup Plus contrast with most of the studies exposing amphibians to glyphosate formulations. However, many of these studies used tadpoles instead of embryos as target organisms (e.g., Mann and Bidwell 1999; Relyea 2005b, 2009; Relyea and Jones 2009). However, in agreement with our results, amphibian embryos have been found to be much more resistant than tadpoles to glyphosate-related mortality. For example, Edginton et al. (2004) observed that Bufo americanus, R. clamitans, X. laevis and R. pipiens tadpoles were, respectively, 1.5, 3.8, 6.8, and 8.9 times more sensitive to the herbicide than their corresponding embryos. A possible reason why embryos could be that 
Table 3 Results of statistical tests to analyse the effects of $\mathrm{NO}_{3} \mathrm{NH}_{4}$ and Roundup on hatching time, length at hatching, and developmental stage at hatching of C. lusitanica

\begin{tabular}{|c|c|c|c|c|c|}
\hline Variable & Source of variation & $\begin{array}{l}\text { Sum of } \\
\text { squares }\end{array}$ & df & $\mathrm{F}$ & $\mathrm{p}$ \\
\hline \multirow[t]{4}{*}{ Time $^{\mathrm{a}}$} & $\mathrm{NO}_{3} \mathrm{NH}_{4}$ & 0.0058 & 2 & 1.073 & 0.357 \\
\hline & Roundup & 0.0067 & 2 & 1.244 & 0.305 \\
\hline & $\mathrm{NO}_{3} \mathrm{NH}_{4} 9$ Roundup & 0.0176 & 4 & 1.622 & 0.200 \\
\hline & Error & 0.0676 & 25 & 0.003 & \\
\hline \multirow[t]{7}{*}{ Length $^{\mathrm{b}}$} & Hatching time $^{c}$ & 0.0096 & 1 & 22.005 & $\checkmark .001$ \\
\hline & $\mathrm{NO}_{3} \mathrm{NH}_{4}$ & 0.0003 & 2 & 0.419 & 0.663 \\
\hline & Roundup & 0.0033 & 2 & 3.754 & 0.038 \\
\hline & $\begin{array}{l}\text { Hatching } \\
\text { time }^{\mathrm{c}} \mathbf{9} \mathrm{NO}_{3} \mathrm{NH}_{4}\end{array}$ & 0.0001 & 2 & 0.117 & 0.890 \\
\hline & $\begin{array}{l}\text { Hatching } \\
\text { time }^{\mathrm{9}} \mathbf{9} \text { Roundup }\end{array}$ & 0.0001 & 2 & 0.108 & 0.898 \\
\hline & $\mathrm{NO}_{3} \mathrm{NH}_{4} 9$ Roundup & 0.0073 & 4 & 4.190 & 0.010 \\
\hline & Error & 0.0104 & 24 & & \\
\hline \multirow[t]{7}{*}{ Stage $^{b}$} & Hatching time $^{c}$ & 0.0078 & 1 & 35.770 & ○.001 \\
\hline & $\mathrm{NO}_{3} \mathrm{NH}_{4}$ & 0.0003 & 2 & 0.640 & 0.536 \\
\hline & Roundup & 0.0005 & 2 & 1.244 & 0.306 \\
\hline & $\begin{array}{l}\text { Hatching } \\
\text { time }^{\mathrm{c}} \mathbf{9} \mathrm{NO}_{3} \mathrm{NH}_{4}\end{array}$ & 0.0001 & 2 & 0.199 & 0.821 \\
\hline & $\begin{array}{l}\text { Hatching } \\
\text { time }^{\mathrm{C}} \mathbf{9} \text { Roundup }\end{array}$ & 0.0002 & 2 & 0.455 & 0.641 \\
\hline & $\mathrm{NO}_{3} \mathrm{NH}_{4} 9$ Roundup & 0.0017 & 4 & 1.919 & 0.140 \\
\hline & Error & 0.0052 & 24 & & \\
\hline
\end{tabular}

a Test used: two-way ANOVA

b Test used: two-way ANCOVA

c Variable used as covariate

tolerant would be the protection provided by the gelatinous envelope, as has been demonstrated for some pollutants (e.g., Edginton et al. 2007). However, the jelly coat has been found to be ineffective against some other chemicals (e.g., Bridges 2000) and, given the chemical properties of glyphosate and POEA, this jelly coat does not seem likely to prevent diffusion toward the egg.

Another possible explanation for the high embryonic resistance would be the absence of specific tissues or organs potentially sensitive to the herbicide's toxic effects. Those target tissues are unknown in amphibians, but it has been shown in fish that the surfactants that are added to the glyphosate commercial formulations cause cellular lysis in the branchial epithelium (Partearroyo et al. 1991).Hatchling C. lusitanica still present their gills in an incipient developmental status (Vences 2009).Thus, this target tissue would not be present during most of the embryonic life, perhaps decreasing the potential toxicity of POEA and other surfactants on embryos.

With regard to sublethal responses, the absence of effects of ammonium nitrate on length at hatching and embryonic
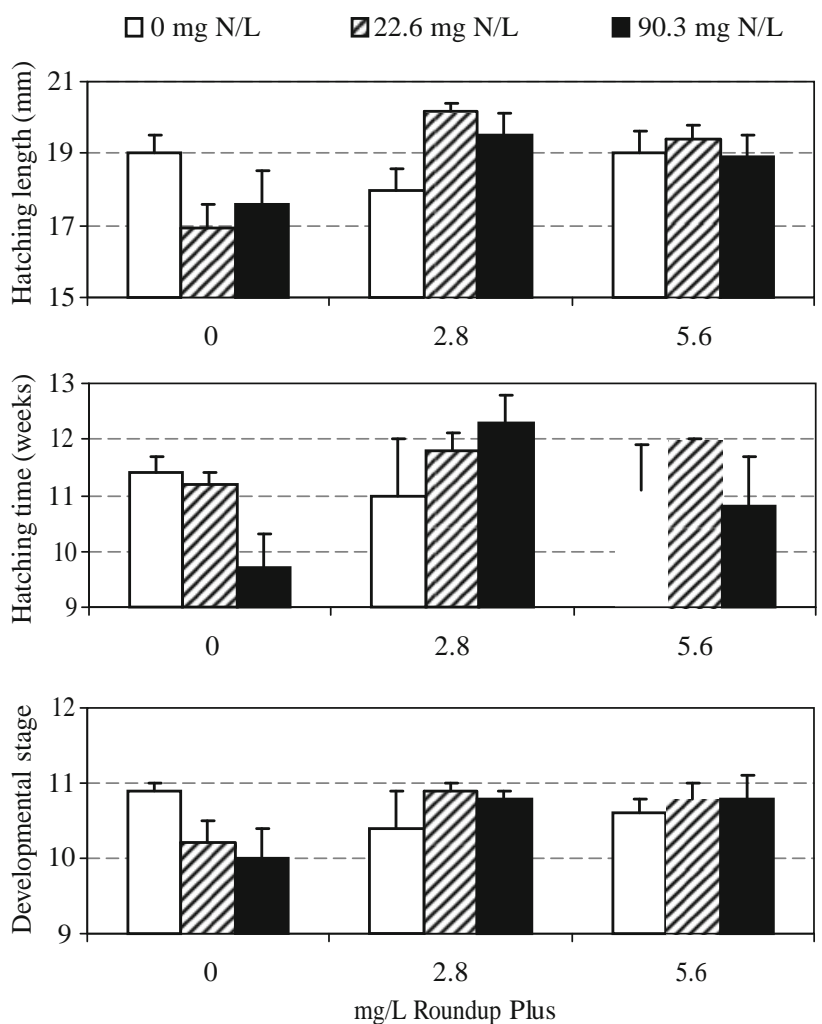

Fig. 3 Mean (?SE) values for hatching length, time, and developmental stage of C. lusitanica embryos exposed to different concentrations of ammonium nitrate (mg N/L) and Roundup Plus. For developmental stage explanation, see Table 1

development is more surprising than the results regarding mortality. In the only published article of which we are aware that analyses the effects of ammonium nitrate on urodele embryos, Ortiz-Santaliestra et al. (2007) reported lower length and developmental stage at hatching in $\mathrm{T}$. pygmaeus exposed to $90.3 \mathrm{mg} \mathrm{N}-\mathrm{NO}_{3} \mathrm{NH}_{4} / \mathrm{L}$ compared with controls. Likewise, in a recent study, we found the same effects when exposing $\mathrm{L}$. boscai to the same ammonium nitrate level (Ortiz-Santaliestra, 2010, unpublished data). Other studies analysing the effects of nitrogenous compounds on the embryonic development of urodeles are coincident in pointing at the sublethal depression of growth and development (Griffis-Kyle 2007; Meredith and Whiteman 2008).

The most relevant effect of the exposure to the agrochemicals used in the present study was the increase of the total length at hatching of individuals exposed to Roundup Plus, either alone or in combination with ammonium nitrate. In the literature, we have not found any report of such an effect caused by a pollutant on amphibian embryos, with the exception of those cases in which larger hatchlings occur as an indirect consequence of a longer embryonic development. Only exposure to certain predators has been shown to induce morphologic variations during embryonic development. For example, Laurila et al. 
(2002) observed that when embryos were incubated in the presence of leeches, hatchlings had flatter tails than those incubated without predatory risk signals. Laurila et al. (2001) also observed that 2-day-old R. temporaria larvae also exhibited morphologic variations induced by the presence of aquatic beetles. Nevertheless, these predatorinduced morphologies are not usually accompanied by an increase in body size, and nothing is known about the possibility that contaminants may cause similar effects on embryos and hatchlings. Positive effects of herbicides or nitrogenous fertilizers on amphibian length have been reported for tadpoles and metamorphs (e.g., $\mathrm{Xu}$ and Oldham 1997; Ortiz et al. 2004; Relyea 2009). However, those studies performed with tadpoles were logically influenced by factors, such as the effects of the chemicals on the availability of food, which have no influence on embryonic development.

Embryonic growth depends on water absorption, availability of vitelline reserves (Crump and Kaplan 1979), and concentration of dissolved oxygen (Seymour and Bradford 1987). Because of the experimental design, with a random distribution of the eggs across the different containers, it is unlikely that the vitelline energetic reserves would have constituted a source of variation among treatments.

Water absorption by the egg is conditioned by the structural characteristics of the gelatinous envelope as well as by the osmotic balance between the inner and outer spaces of the egg. Likewise, oxygen diffusion toward the egg relies on a gradient of partial pressures (Mitchell and Seymour 2003). This gradient basically depends on three properties of the jelly coat (Seymour 1995): shape, thickness, and permeability. We did not observe any effect of Roundup Plus on visible morphology, either in shape or thickness, of the embryonic envelopes. In contrast, the gelatinous envelope that protects amphibian eggs is highly permeable to the diffusion of hydrophilic substances because of its composition of glycoproteins, mucoproteins, carbohydrates, and mucopolysaccharides (Salthe 1963). Both glyphosate and POEA are highly hydrophilic and thereby have potential to diffuse through the gelatinous layer and alter its structure, analogous to what they present when acting on vegetal envelopes (Hess and Foy 2000). This alteration would modify the permeability of the jelly coat, thus allowing a higher influx of water and oxygen toward the inner space of the egg; this could ultimately favour embryonic growth. The effects of Roundup on embryonic envelopes should be investigated to elucidate the potential reasons why the exposure to the herbicide increased hatchling length.

The ecologic consequences of a larger hatching size, such as that showed by individuals exposed to Roundup Plus, are not clear. Under certain circumstances, a larger size may contribute to increased probability of survival (e.g., Räsänen et al. 2005). In contrast, a higher vulnerability to predation by larger tadpoles has been shown (e.g., Warkentin 1999). Further research should be conducted to determine how this potential effect of Roundup Plus on the embryonic growth of C. lusitanica plays out among individuals in their natural environments.

Acknowledgements Armando Loureiro, Fernando Sequeira, Claudia Soares, and Neftalí Sillero facilitated the paperwork and helped with egg collection.

\section{References}

Arntzen JW (1981) Ecological observations on Chioglossa lusitanica (Caudata, Salamandridae). Amphibia-Reptilia 1:187-203

Arntzen JW, Bosch J, Denoël M, Tejedo M, Edgar P, Lizana M et al (2009) Chioglossa lusitanica. In: IUCN red list of threatened species. Version 2009.2. International Union for Conservation of Nature, Gland, Switzerland. Available at: http://www.iucnredlist. org. Accessed 1 February 2010

Blaustein AR, Romansic JM, Kiesecker JM, Hatch AC (2003) Ultraviolet radiation, toxic chemicals and amphibian population declines. Divers Distrib 9:123-140

Boone MD, James SM (2003) Interactions of an insecticide, herbicide, and natural stressors in amphibian community mesocosms. Ecol Appl 13:829-841

Boone MD, Bridges CM, Fairchild JF, Little EE (2005) Multiple sublethal chemicals negatively affect tadpoles of the green frog, Rana clamitans. Environ Toxicol Chem 24:1267-1272

Boone MD, Semlitsch RD, Little EE, Doyle MC (2007) Multiple stressors in amphibian communities: effects of chemical contamination, bullfrogs and fish. Ecol Appl 17:291-301

Bridges CM (2000) Long-term effects of pesticide exposure at various life stages of the southern leopard frog (Rana sphenocephala). Arch Environ Contam Toxicol 39:91-96

Carneiro M, Fabião A, Martins MC, Fabião A, Abrantes da Silva M, Hilário L et al (2008) Effects of harrowing and fertilisation on understory vegetation and timber production of a Eucalyptus globulus Labill plantation in Central Portugal. For Ecol Manage 255:591-597

Crump ML, Kaplan RH (1979) Clutch energy partitioning of tropical tree frogs (Hylidae). Copeia 1979:626-635

Edginton AN, Sheridan PM, Stephenson GR, Thompson DG, Boermans HJ (2004) Comparative effects of $\mathrm{pH}$ and Vision ${ }^{\circledR}$ herbicide on two life stages of four anuran species amphibian species. Environ Toxicol Chem 23:815-822

Edginton AN, Rouleau C, Stephenson GR, Boermans HJ (2007) 2,4-D butoxyethyl ester kinetics in embryos of Xenopus laevis: the role of the embryonic jelly coat in reducing chemical absorption. Arch Environ Contam Toxicol 52:113-120

Egea-Serrano A, Tejedo M, Torralva M (2009) Populational divergence in the impact of three nitrogenous compounds and their combination on larvae of the frog Pelophylax perezi (Seoane, 1885). Chemosphere 76:869-877

Eisler R (1989) Atrazine hazards to fish, wildlife and invertebrates: a synoptic review. Biological report 85/1.18. United States Fish and Wildlife Service, Washington, DC

Faul F, Erdfelder E, Buchner A, Lang AG (2009) Statistical power analyses using $G^{*}$ Power 3.1 : tests for correlation and regression analyses. Behav Res Methods 41:1149-1160

Fontes A (2008) Revisão do Plano de Ordenamento do Parque Nacional de Peneda-Gerês. Instituto da Conservação da Naturaza e da Biodiversidade, Lisbon, Spain 
Giesy JP, Dobson S, Solomon KR (2000) Ecotoxicological risk assessment for Roundup ${ }^{\circledR}$ herbicide. Rev Environ Contam Toxicol 167:35-120

Griffis-Kyle KL (2007) Sublethal effects of nitrite on eastern tiger salamander (Ambystoma tigrinum tigrinum) and wood frog (Rana sylvatica) embryos and larvae: Implications for field populations. Aquat Ecol 41:119-127

Harrison RG (1969) Harrison stages and description of the normal development of the spotted salamander, Ambystoma punctatum (Linn.). In: Harrison RG (ed) Organization and development of the embryo. Yale University Press, New Haven, CT, pp 44-66

Hatch AC, Blaustein AR (2000) Combined effects of UV-B, nitrate, and low $\mathrm{pH}$ reduce the survival and activity level of larval Cascades frogs (Rana cascadae). Arch Environ Contam Toxicol 39:494-499

Hatch AC, Blaustein AR (2003) Combined effects of UV-B radiation and nitrate fertilizer on larval amphibians. Ecol Appl 13:1083-1093

Hess FD, Foy CL (2000) Interaction of surfactants with plant cuticles. Weed Technol 14:803-807

Howe CM, Berrill M, Pauli BD, Helbing CC, Werry K, Veldhoen V (2004) Toxicity of glyphosate-based pesticides to four North American frog species. Environ Toxicol Chem 23:1928-1938

Johnson PTJ, Preu ER, Sutherland DR, Romansic JM, Han B, Blaustein AR (2006) Adding infection to injury: synergistic effects of predation and parasitism on amphibian malformations. Ecology 87:2227-2235

Laposata MM, Dunson WA (1998) Effects of boron and nitrate on hatching success of amphibian eggs. Arch Environ Contam Toxicol 35:615-619

Laurila A, Crochet PA, Merilä J (2001) Predator-induced effects on hatchling morphology in the common frog (Rana temporaria). Can J Zool 79:926-930

Laurila A, Pakkasmaa S, Crochet PA, Merilä J (2002) Predatorinduced plasticity in early life history and morphology in two anuran amphibians. Oecologia 132:524-530

Macías G, Marco A, Blaustein AR (2007) Combined exposure to ambient UVB radiation and nitrite negatively affects survival of amphibian early life stages. Sci Tot Environ 385:55-65

Mann RM, Bidwell JR (1999) The toxicity of glyphosate and several glyphosate formulations to four species of Southwestern Australian frogs. Arch Environ Contam Toxicol 36:193-199

Mann R, Hyne RV, Choung CB, Wilson SP (2009) Amphibians and agricultural chemicals: review of the risks in a complex environment. Environ Pollut 157:2903-2927

Meredith CS, Whiteman HH (2008) Effects of nitrate on embryos of three amphibian species. Bull Environ Contam Toxicol 80:529-533

Mitchell NJ, Seymour RS (2003) The effects of nest temperature, nest substrate and clutch size on the oxygenation of embryos and larvae of the Australian moss frog, Bryobatrachus nimbus. Physiol Biochem Zool 76:60-71

Oldham RS, Latham DM, Hilton-Brown D, Towns M, Cooke AS, Burn A (1997) The effect of ammonium nitrate fertiliser on frog (Rana temporaria) survival. Agric Ecosyst Environ 61:69-74

Ortiz ME, Marco A, Saiz N, Lizana M (2004) Impact of ammonium nitrate on growth and survival of six European amphibians. Arch Environ Contam Toxicol 47:234-239

Ortiz-Santaliestra ME, Marco A, Fernández MJ, Lizana M (2006) Influence of developmental stage on sensitivity to ammonium nitrate of aquatic stages of amphibians. Environ Toxicol Chem 25:105-111

Ortiz-Santaliestra ME, Marco A, Fernández-Benéitez MJ, Lizana M (2007) Effects of ammonium nitrate exposure and water acidification on the dwarf newt: the protective effect of oviposition behaviour on embryonic survival. Aquat Toxicol 85:251-257

Orton F, Carr JA, Handy RD (2006) Effects of nitrate and atrazine on larval development and sexual differentiation in the Northern leopard frog Rana pipiens. Environ Toxicol Chem 25:65-71

Partearroyo MA, Pilling SJ, Jones MN (1991) The lysis of isolated fish (Oncorhynchus mykiss) gill epithelial cells by surfactants. Comp Biochem Physiol C 100:381-388

Räsänen K, Laurila A, Merilä J (2005) Maternal investment in egg size: environment- and population-specific effects on spring performance. Oecologia 142:546-553

Relyea RA (2005a) The impact of insecticides and herbicides on the biodiversity and productivity of aquatic communities. Ecol Appl 15:618-627

Relyea RA (2005b) The lethal impacts of Roundup and predatory stress on six species of North American tadpoles. Arch Environ Contam Toxicol 48:351-357

Relyea RA (2006) Response on the impact of herbicides and pesticides on the biodiversity and productivity of aquatic communities. Ecol Appl 16:2027-2034

Relyea RA (2009) A cocktail of contaminants: how mixtures of pesticides at low concentrations affect aquatic communities. Oecologia 159:363-376

Relyea RA, Jones DK (2009) The toxicity of Roundup Original Max ${ }^{\circledR}$ to 13 species of larval amphibians. Environ Toxicol Chem 28:2004-2008

Relyea RA, Mills N (2001) Predator-induced stress makes the pesticide carbaryl more deadly to gray treefrog tadpoles (Hyla versicolor). Proc Nat Acad Sci USA 98:2491-2496

Salthe SN (1963) The egg capsules in the amphibian. J Morphol 113:161-171

Schuytema GS, Nebeker AV (1999) Comparative effects of ammonium and nitrate compounds on Pacific treefrog and African clawed frog embryos. Arch Environ Contam Toxicol 36: 200-206

Sequeira F, Ferrand N, Crespo EG (2003) Reproductive cycle of the golden-striped salamander Chioglossa lusitanica (Caudata, Salamandridae) in NW Portugal. Amphibia-Reptilia 24:1-12

Seymour RS (1995) Oxygen uptake by embryos in gelatinous egg masses of Rana sylvatica: the roles of diffusion and convection. Copeia 1995:626-635

Seymour RS, Bradford DF (1987) Gas exchange through the jelly capsule of the terrestrial eggs of the frog, Pseudophryne bibroni. J Comp Physiol B 157:477-481

Sullivan KB, Spence KM (2003) Effects of sublethal concentrations of atrazine and nitrate on metamorphosis of the African clawed frog. Environ Toxicol Chem 22:627-635

Thompson DG, Wojtaszek BF, Staznik B, Chartrand DT, Stephenson GR (2004) Chemical and biomonitoring to assess potential acute effects of Vision ${ }^{\circledR}$ herbicide on native amphibian larvae in forest wetlands. Environ Toxicol Chem 23:843-849

Thompson DG, Solomon KR, Wojtaszek BF, Edginton AN, Stephenson GR (2006) The impact of insecticides and herbicides on the biodiversity and productivity of aquatic communities. Ecol Appl 16:2022-2027

Vences M (1990) Untersuchungen zur ökologie, ethologie und geographischen variation von Chioglossa lusitanica Bocage, 1864. Salamandra 26:267-297

Vences M (2009) Salamandra rabilarga-Chioglossa lusitanica. In: Salvador A (ed) Enciclopedia virtual de los vertebrados españoles. Museo Nacional de Ciencias Naturales, Madrid. Available at: http://www.vertebradosibericos.org. Accessed 2 February 2010

Vitousek PM, Aber J, Howarth RW, Likens GE, Matson PA, Schindler DW et al (1997) Human alteration of the global nitrogen cycle: causes and consequences. Issues Ecol 1:1-16 
Warkentin KM (1999) Effects of hatching age on development and hatchling morphology in the red-eyed treefrog, Agalychnis callidryas. Biol J Linn Soc 68:443-470

Watt PJ, Oldham RS (1995) The effect of ammonium nitrate on the feeding and development of larvae of the smooth newt, Triturus vulgaris (L.), and on the behaviour of its food source, Daphnia. Freshw Biol 33:319-324

Xu Q, Oldham RS (1997) Lethal and sublethal effects of nitrogen fertilizer ammonium nitrate on common toad (Bufo bufo) tadpoles. Arch Environ Contam Toxicol 32:298-303 